\title{
A Comprehensive Review on the Corrosion Pathways of Titanium Dental Implants and Their Biological Adverse Effects
}

\author{
Júlio C. M. Souza ${ }^{1,2, *}$, Karin Apaza-Bedoya ${ }^{3}{ }^{\mathbb{C}}$, Cesar A. M. Benfatti ${ }^{3}{ }^{\mathbb{D}}$, Filipe S. Silva ${ }^{1}$ \\ and Bruno Henriques 1,4 \\ 1 Center for MicroElectroMechanical Systems (CMEMS-UMinho), University of Minho, \\ 4800-058 Guimarães, Portugal; fsamuel@dem.uminho.pt (F.S.S.); brunohenriques@dem.uminho.pt (B.H.) \\ 2 Department of Dental Sciences, University Institute of Health Sciences (IUCS), CESPU, \\ 4585-116 Gandra PRD, Portugal \\ 3 Center for Research and Education in Implant Dentistry (CEPID), Post-Graduate Program in \\ Dentistry (PPGO), School of Dentistry (ODT), Federal University of Santa Catarina (UFSC), \\ Florianopolis/SC 88040-900, Brazil; karin_ab@hotmail.com (K.A.-B.); cesarbenfatti@yahoo.com (C.A.M.B.) \\ 4 Ceramic and Composite Materials Research Group (CERMAT), Department of Mechanical \\ Engineering (EMC), Campus Trindade, Federal University of Santa Catarina (UFSC), \\ Florianópolis/SC 88040-900, Brazil \\ * Correspondence: jsouza@dem.uminho.pt
}

Received: 20 July 2020; Accepted: 10 September 2020; Published: 22 September 2020

\begin{abstract}
The main aim of this work was to perform a comprehensive review of findings reported by previous studies on the corrosion of titanium dental implants and consequent clinical detrimental effects to the patients. Most studies were performed by in vitro electrochemical tests and complemented with microscopic techniques to evaluate the corrosion behavior of the protective passive oxide film layer, namely $\mathrm{TiO}_{2}$. Results revealed that bacterial accumulation, dietary, inflammation, infection, and therapeutic solutions decrease the $\mathrm{pH}$ of the oral environment leading to the corrosion of titanium. Some therapeutic products used as mouthwash negatively affect the corrosion behavior of the titanium oxide film and promote changes on the implant surface. In addition, toothpaste and bleaching agents, can amplify the chemical reactivity of titanium since fluor ions interacting with the titanium oxide film. Furthermore, the number of in vivo studies is limited although corrosion signs have been found in retrieved implants. Histological evaluation revealed titanium macro- and micro-scale particles on the peri-implant tissues. As a consequence, progressive damage of the dental implants and the evolution of inflammatory reactions depend on the size, chemical composition, and concentration of submicron- and nanoparticles in the surrounding tissues and internalized by the cells. In fact, the damage of the implant surfaces results in the loss of material that compromises the implant surfaces, implant-abutment connections, and the interaction with soft tissues. The corrosion can be an initial trigger point for the development of biological or mechanical failures in dental implants.
\end{abstract}

Keywords: corrosion; dental implants; titanium; peri-implantitis

\section{Introduction}

Among the currently available biomedical materials, the long-term success rates of titanium-based dental implants have supported the use of titanium and its alloys to manufacture implants and prosthetic devices [1,2]. Thus, the clinical success of titanium implants is a consequence of their physicochemical properties, high corrosion resistance, and biocompatibility [1,2]. The corrosion resistance of titanium is linked to the spontaneous formation of a titanium thin oxide film in contact 
with room or oral environment [3-6]. Such oxide film is mainly composed of titanium oxide, $\mathrm{TiO}_{2}$, which has a chemical stability to protect the titanium structure when in contact with body fluids [3-6]. However, the nature, chemical composition, and thickness of the protective oxide layer can be altered in certain environmental conditions, which exposes the titanium to corrosive substances $[7,8]$. Signs of corrosion have been detected on titanium by in vitro electrochemical assays [3-6] that corroborate with in vivo studies on retrieved dental implants $[7,8]$. Furthermore, the release of titanium debris to the surrounding peri-implant tissues was reported by previous studies [4,9-11]. The embedment of micro- and nano-particles in soft tissues stimulates inflammatory cells such as macrophages and neutrophils $[4,9,11]$. It can lead to progressive chronic inflammatory reactions and bone resorption known as peri-implantitis [3,4,9-12].

The oral environment is a challenge for biomedical metallic materials such as titanium once the $\mathrm{pH}$ oscillates due to the variation of acidic substances from dietary, therapeutic solutions, and bacteria metabolism [3-5]. Thus, lactic, hydrochloric, and hydrofluoric acids are the main acidic substances responsible for the corrosion of titanium-based implants in the oral environment [3,13-15]. Additionally, previous studies have shown that the saliva $\mathrm{pH}$ decreases under inflammatory or infection process [3,13-15], or under the influence of factors such as periodontitis disease, habits, systemic disease, and salivary gland radiation $[16,17]$. Regarding the oral biofilm, multi-species agglomerates have been associated with the release of lactic acid, hydrogen peroxide $\left(\mathrm{H}_{2} \mathrm{O}_{2}\right)$, and formic acids from the bacteria metabolism [17-21]. The production of metabolites by microorganisms leads to a higher corrosion susceptibility of titanium due to the decrease in $\mathrm{pH}$. Streptococcus mutans and lactobacillus aa. were linked to the acidic $\mathrm{pH}$ while Porphyromonas gingivalis and Prevotella intermedia were identified as the main species in peri-implantitis $[17,18,22]$. On the other hand, hydrofluoric acid is produced during the presence of a high content of fluoride from commercially fluoridated acidic toothpastes, mouthwashes, or cariostatic gels $[3-5,23-25]$. Titanium has shown a high chemical reactivity to HF that results in corrosion depending on the exposure time and HF content [3-5,23-32].

The main aim of this work was to perform a comprehensive review of findings reported by previous studies on the corrosion of titanium dental implants and consequent clinical adverse effects to the patients. Several factors related to the corrosion of titanium are described such as the type of titanium, oral environment, therapeutic agents, acidic substances, and oral biofilm. Therefore, the present work aims to summarize the current data regarding the clinical significance of implant corrosion and how such a phenomenon is widespread in clinical practice.

\section{Corrosive Aspects of the Oral Environment}

The oral environment is complex since intrinsic patient-related factors are involved such as patient health, bacteria species, $\mathrm{pH}$, saliva composition, glycoproteins, and temperature $[4,5,33]$. Furthermore, therapeutic substances, dietary, oral hygiene, and patient's habits are extrinsic factors that influence the oral environment $[4,5,33]$. The complexity of the saliva chemical composition becomes a challenge for the performance of any implant material as illustrated in Figure 1.

Saliva plays a key role in the oral environment once the presence of enzymes, minerals, and glycoproteins in combination with a pH buffering mechanism regulate the biofilm formation in the oral cavity [13]. The salivary secretion is constituted of about $99 \%$ water while the remnant proportion is composed of inorganic and organic compounds including minerals and glycoproteins. The following chemical elements can be found: sodium, potassium, chloride, calcium, phosphate, and bicarbonate, fluor, thiocyanate, magnesium, sulfate, and iodide [34]. However, the $\mathrm{pH}$ buffering mechanism can be limited by a high density of microbial cells or by a low salivary flow rate [3]. The saliva $\mathrm{pH}$ secreted by salivary glands varies between 6 and 7 although the salivary $\mathrm{pH}$ oscillates depending on the presence of other substances and bacteria [3,14]. For instance, the saliva $\mathrm{pH}$ can achieve acidic levels at around 2.0 on intake of citric or acidic solutions [17]. Also, the $\mathrm{pH}$ of saliva could vary in regions around surgical sites, dental implants, and restorative margins. After the placement of a dental implant, the 
$\mathrm{pH}$ decreases down to 5.2-5.6 due to the inflammatory process or infections [15] although the $\mathrm{pH}$ can recover at 7.0-7.4 under healthy state conditions after 2 weeks [15].

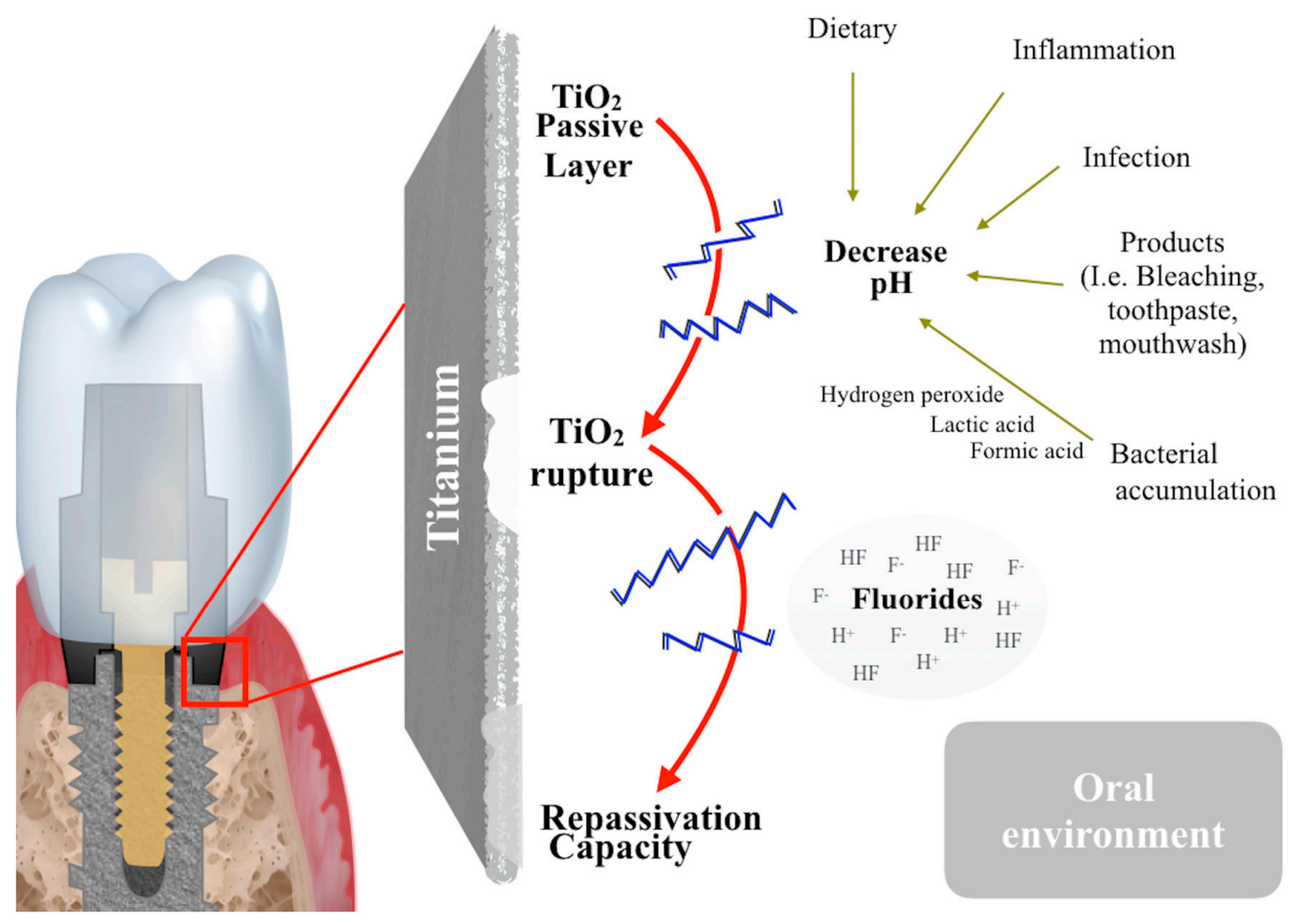

Figure 1. Factors that affect the corrosion behavior of the titanium.

An imbalance in the chemical composition of the saliva can increase the concentration of ions like $\mathrm{Cl}^{-}, \mathrm{F}^{-}$, and $\mathrm{H}^{+}$, which are the dominant chemical elements responsible for the corrosion of dental materials including titanium [33]. Thus, fluor ion concentrations levels ranging from 20 to $227 \mathrm{ppm}$ were found in oral biofilms after the use of ordinary toothpastes containing 1000 to $1500 \mathrm{ppm} \mathrm{F}^{-}$[35]. Also, high content of fluorides are found in prophylactic commercial products or hypersensitivity treatment like mouth rinses or cariostatic gels [25]. A high concentration of fluorides in saliva promotes an association between $\mathrm{H}^{+}$an $\mathrm{F}^{-}$ions, resulting in the formation of hydrofluoric acid (HF) [25]. Hydrofluoric acid is chemically considered a week acid although a strongly reactive agent to metallic materials, including titanium [24]. Previous studies reported a decrease in the corrosion resistance of titanium and its alloys in contact with fluorinated solutions [3,4,23,24]. Only a concentration of about $0.7 \mathrm{ppm} \mathrm{F}^{-}$can be present in food or tap water, which is a low content to form the reactive hydrofluoric acid [4]. Localized corrosion occurs even at lower concentrations of $\mathrm{F}^{-}$in an acidic environment due to the formation of HF. Other corrosive substances such as carbamide (urea) and hydrogen peroxide can be found in bleaching compounds. The use of urea and hydrogen peroxide for bleaching treatment was linked to the corrosion of titanium surfaces [24]. On the therapeutic treatment of peri-implantitis, solutions containing citric or phosphoric acids are often utilized to eradicate bacteria from the titanium surfaces. Those solutions decrease the $\mathrm{pH}$ and therefore can speed up the corrosion of titanium [4]. Nevertheless, the corrosive effect of fluorides and therapeutic agents depends upon the exposure time, $\mathrm{pH}$, and concentration surrounding the titanium surfaces $[3,4,23,24]$.

Surfaces of oral tissues, teeth, restorative materials, and implants can be coated with biofilms that consist of a microorganism's community embedded in an extracellular matrix composed of polysaccharides, proteins, nucleic acids, and water. Bacterial colonization on the surface of dental implants can occur within $30 \mathrm{~min}$ after the placement surgery of trans-mucosal implant $[21,36]$. As a result, the $\mathrm{pH}$ decreases due to the release of acidic substances from oral microbial metabolism [3]. According to previous studies, streptococci species were mostly found surrounding the dental implants. 
Hydrophobic microorganisms perform their initial adhesion on titanium surfaces supported by glycoprotein as e.g., mucin or polysaccharides extracellular matrix [18]. Then, secondary species such as Fusobacterium nucleatum establish the binding with the primary Streptococci, extracellular matrix, and the later colonizers (e.g., Porphyromonas gingivalis and Prevotella intermedia) [21,36]. The biofilm formation depends on the features of the peri-implant tissues and the topography of the implant surface. Thus, retentive macro- and micro-regions or prosthetic connections are susceptible to dietary food embedment and biofilm accumulation, leading to peri-implant inflammation and conditions that negatively affect the corrosion resistance of titanium [3,37]. Anyway, bacteria have been found at titanium implant-abutment or abutment-crown joints, and on the apical portion of the titanium abutment screw [38,39].

\section{Titanium Implant Surface}

Titanium is a very reactive metal once it is a transition chemical element and has an incomplete filled shell in its electronic structure [40]. Ti exists in two allotropic forms, namely a body-centered cubic structure $(\beta)$ or a hexagonal closed packed crystal structure $(\alpha)$. Titanium can be alloyed with other chemical elements for manufacturing of alloys. Alloying elements such as $\mathrm{Al}, \mathrm{O}, \mathrm{N}$, and $\mathrm{C}$ tend to stabilize the $\alpha$ phase while $\mathrm{V}, \mathrm{Mo}, \mathrm{Nb}, \mathrm{Ta}, \mathrm{Fe}, \mathrm{Cr}, \mathrm{Fe}, \mathrm{W}, \mathrm{Si}, \mathrm{Co}, \mathrm{Mn}$, and $\mathrm{H}$ stabilize the $\beta$ phase. Alloys with a low elastic modulus have revealed a stabilized $\beta$ phase. Titanium-based alloys are classified within the degree of purity that depends on the content of $\mathrm{Ti}$ in the chemical composition. Commercially pure titanium $(\mathrm{Cp} \mathrm{Ti})$ is divided into four degrees depending on the content of oxygen, carbon, and iron. Cp Ti grade IV containing approximately $98.6 \% \mathrm{Ti}$ is the first choice titanium type to manufacture the endosseous implant fixture. Cp TI grade IV shows both $\alpha+\beta$ phases in the microstructure and it results in an elastic modulus around $110 \mathrm{GPa}$ and tensile strength at around $560 \mathrm{MPa}$ [1,3-5]. Titanium alloys such Ti15Zr are also used to manufacture the endosseous implant fixture while Ti6Al4V alloys are utilized to manufacture implant abutment for prosthetic connections [1,3-5].

In fact, titanium is the most widely used material for dental implants and abutments due to their high biocompatibility and properties such as a strength, corrosion resistance, and fatigue resistance [41]. The thermal stability of titanium is crucial during the manufacturing of the dental implants by machining and physicochemical processes. In the oral environment, dietary intake of hot drinks can also increase the temperature in association with loading and micro-movements from mastication. The high corrosion resistance of titanium is the consequence of its high affinity to oxygen and the formation of a titanium oxide thin film within $30 \mathrm{~ms}$ [5,42]. Such titanium oxide thin layer is also known as passive film. The passive thin film comprises between 1 and $20 \mathrm{~nm}$ thickness of a continuous, low-crystalline, and non-stoichiometric oxide film with a relative thermodynamic stability and high adherence [3]. Three forms of titanium oxides can spontaneously cover the freshly exposed titanium: rutile, anatase, and brookite. Rutile form reveals more crystalline structure and consequently, higher chemical stability than the anatase form [3]. High temperature oxidation induces the formation of rutile form of titanium oxide, while a mixture of rutile and anatase is formed at low temperature oxidation reaction. The titanium thin oxide film is mainly composed of titanium oxide $\left(\mathrm{TiO}_{2}\right)$, depending on the conditions in which it was formed [23]; although $\mathrm{TiO}$, $\mathrm{TiO}(\mathrm{OH})$ or $\mathrm{Ti}_{2} \mathrm{O}_{3}$ can be found in the chemical composition of the titanium oxide layer. However, $\mathrm{Ti}_{2} \mathrm{O}_{3}$ is rapidly converted to $\mathrm{TiO}(\mathrm{OH})_{2}$ at air atmosphere and, then into $\mathrm{TiO}_{2}$ after reaction with $\mathrm{H}_{2} \mathrm{O}$ molecules [43,44]. The titanium oxide thin layer acts as a barrier film on the surface of the newly placed implant, offering a chemical barrier from further oxidation, and it prevents the release of deeper metal atoms.

Taking into account the properties of the titanium, several physicochemical methods are industrially used to modify the titanium surface to enhance the osseointegration of the implant [43-46]. The passivation of the titanium oxide layer can be improved by modifying the thickness, morphologic aspects, or chemical composition of the surface oxide layer using different physicochemical methods. Etching procedures with reactive acid solutions containing $\mathrm{HCl}, \mathrm{HNO}_{3}, \mathrm{H}_{2} \mathrm{SO}_{4}$, and $\mathrm{HF}$ are ordinary 
surface modification methods of titanium implants. The acid etching procedure using hydrofluoric acid modifies the chemical composition of the titanium oxide thin film by incorporating $\mathrm{F}$ atoms (e.g., $\mathrm{TiOF}_{2}, \mathrm{TiOHF}$ ) [43]. Studies revealed a high corrosion resistance of acid etched titanium surfaces when compared to surfaces free of acid etching. Additionally, further surface modification methods are applied to improve the corrosion resistance of titanium implants such as coating deposition, electrochemical passivation, ion beam processing, and surface functionalization [15]. Anodization is a well-known method for the modification of titanium surface with different types of protective oxide films. That can enhance the corrosion resistance and delay the release of metal ions to the surrounding environment [46]. The electrochemical modification of titanium surfaces is applied to dissolve the existing titanium oxide and re-establish a standard surface for the formation of more stable $\mathrm{TiO}_{2}$-rutile crystalline lattice, and thus improving their corrosion resistance $[15,44]$. Laser irradiation procedures for the surface modification improve the corrosion and wear resistance of metal alloys, due to its intrinsic properties of high consistency and texturizing control. Biocompatible and chemically stable coatings are the most successful coating deposition method to prevent corrosion. Recently, ion-beam surface modification technique has been introduced to perform a deposition of thin layer of different bioactive coatings [15]. Surface coating of bioactive materials such as hydroxyapatite, graphene and $\mathrm{CaSiO}_{3}$ improves the osseointegration besides enhancing corrosion resistance in contact with the human body fluids [15]. A previous in vitro study reported a higher corrosion resistance of titanium coated with electrolytic porous coatings of hydroxyapatite or hydroxyapatite/calcium silicate than that on bared titanium [47]. Actually, the porous bioactive layer is composed of bioactive ceramics to mainly enhance the osseointegration process. Additionally, the bioactive ceramic layer acts as a barrier against the corrosion in contact with body fluids. Recent studies described diamond-like carbon as one of the promising corrosion-resistant coatings. The graphene composite coating, produced by electrophoretic deposition on titanium, also displays a porous bioactive layer with enhanced corrosion resistance and antibacterial activity against Staphylococcus aureus and Escherichia coli [48].

\section{Corrosion Processes and Measurement on Titanium Surfaces}

Different forms of corrosion have been noted on the surfaces of dental implant and abutment. General or uniform corrosion takes place when the entire surface of the metal is exposed to the cathodic reactants, resulting in a propagation of corrosion nucleus. Pitting corrosion is a localized form of corrosion in which cavities, known as pits on the surface, are considered to be more dangerous than general corrosion due to the difficulty to detect, predict, and design. On titanium dental implants, pitting corrosion occurs when the titanium oxide thin layer breaks down locally in the oral environment. Galvanic corrosion occurs with direct contact of two dissimilar metals in an electrolytic solution. Galvanic corrosion occurs on the inner contacting surfaces of titanium implant-abutment connections (Figure 1). The surface damage can be increased when other basic metal alloys are used for abutments (e.g., stainless-steel and CoCr alloys). Crevice corrosion is a type of local surface damage at contacting interfaces between implants, abutments, and prosthetic structures (Figure 1) with restricted ingress and egress of oral fluids and depletion of oxygen. In these restricted contacting areas, physiological fluid becomes acidic, reducing the $\mathrm{pH}$ values due to the presence of free $\mathrm{H}^{+}$ions in the medium $[7,31,34,49]$. Also, the dynamic mastication loading generating micro-motion at the implant-abutment connections promotes the wear of contacting surfaces and the premature destruction of the titanium oxide thin film. Thus, the synergistic effect of corrosion and micro-motions causes structural changes and wear on the surfaces resulting in fretting corrosion. This one is responsible for most of the metal release in the surrounding tissues $[15,30,31,49-54]$.

The titanium oxide thin film protects the titanium implant surface against reactive ions from the corrosive oral environment. In spite of a high corrosion resistance, the spontaneously passive film also consists of some inclusions and discontinuity spots due to the microstructure of the titanium and Ti alloy. That influences the quality of the native oxide film and therefore that could become the initial spot for corrosion [44]. Previous studies have shown that the protective titanium oxide film is 
destroyed in the presence of corrosive substances such as fluorides, lactic acid, carbamide peroxide (urea peroxide), and hydrogen peroxide, as seen in Figure $1[3-5,23,24,33,55,56]$. An in vitro study reported the release of Ti ions in an acidic simulated body fluid (SBF) solution of $\mathrm{pH}$ at 2.0 or 3.0 due to the addition of hydrochloric or lactic acid [17]. The amounts of Ti ions increased in both acidic medium for 30 days although were significantly higher in the lactic acid-containing medium than in the hydrochloric acid-containing medium. As a result, the acidic substances reduced the stable titanium oxide thin layer on $\mathrm{cp} \mathrm{Ti}$, increasing the release of Ti ions. It was assumed that the lactic acid binds covalently to Ti ions and suppresses the reprecipitation of the ions, acting as a reducing agent [17]. Nakagawa et al. (1999) reported that the titanium passivation film was damaged by the presence of $\mathrm{F}^{-}$when the HF concentration is higher than about $30 \mathrm{ppm}$ [25]. Hence, corrosion in fluoridated solutions depends on the $\mathrm{pH}$ and the formation of $\mathrm{HF}^{-}$produced by the dissociation of $\mathrm{NaF}$ at high concentrations, or in solutions with low $\mathrm{pH}$ due to the bonding between $\mathrm{H}^{+}$and $\mathrm{F}^{-}$. A high $\mathrm{F}^{-}$concentration combined with a low $\mathrm{pH}$, can intensify the titanium chemical reactivity. Localized corrosion on titanium was detected in fluoridated solutions with $227 \mathrm{ppm} \mathrm{F}^{-}$at $\mathrm{pH} 4.0$; although, that $\mathrm{F}^{-}$content at $\mathrm{pH} 5.5$ was not high enough to disrupt the titanium passive film $[25,35]$. Also, $\mathrm{TiO}_{2}$ layer is altered in the presence of high content of $\mathrm{H}^{+}$from the acidic medium, leading to the formation of hydrated $\mathrm{Ti}$ oxides as $\mathrm{Ti}(\mathrm{OH})^{3+}$ [43], and further to a release of $\mathrm{Ti}^{-}$ions and $\mathrm{TiO}_{2}$ ultra-fine particles to the surrounding environment [18]. The titanium oxide thin film of titanium can also be damaged or modified at high temperature, which can be controlled by the atmosphere and temperature [33]. In the meanwhile, the titanium oxide layer can immediately be renewed after being ruptured in a process named repassivation, as illustrated in Figure $1[3,5,23]$. However, the destruction process of the titanium oxide thin film can be continuous in a medium containing a high content of corrosive substances. In this case of progressive corrosion, the titanium oxide film is classified as active film. Once the titanium oxide thin film is destroyed, further corrosion rate and ions release are highly dependent on the repassivation process. The chemical composition, nature, repassivation process, and thickness of the protective titanium oxide thin film are directly affected by the presence of corrosive substances in the oral environment $[15,16,57]$. In fact, the repassivation of the titanium oxide thin film becomes more challenging in the existence of corrosive substances and micro-motions from mastication loading. Cp Ti reveals a trend to repassivate faster than Ti6Al4V in inorganic buffer solutions. Electrochemical assays showed a lower critical current density and a higher catalytic activity towards the hydrogen evolution reaction on cp Ti when compared to the alloy [57].

The titanium oxide thin layer also adsorbs biomolecules from the oral fluids, such as proteins and carbohydrates. Electrostatic interactions constitute a main pathway involved in the adsorption of a glycoprotein, named mucin. Mucin is a glycoprotein categorized mainly by its high molecular weight and high level of O-linked oligosaccharides. Under physiologic conditions, mucin molecules bind to $\mathrm{Ca}^{2+}, \mathrm{PO}^{4-}$, bacteria, and other polysaccharides and proteins. Calcium ions act as ligands between negatively charged protein molecules and the $\mathrm{Ti}_{\mathrm{x}} \mathrm{O}_{\mathrm{y}}$ surface [58]. Minerals and glycoproteins also establish the binding between the titanium surface and primary bacterial colonizers in the process of biofilm formation. Additionally, biofilms accumulate organic acids from bacteria metabolism, especially lactic and formic acids, which acidify the saliva and promote the corrosion of structural materials $[19,20]$. Biofilm accumulation is an essential factor that can cause failure of the oral rehabilitation system since specific types of acid-producing bacteria can promote the degradation of hard tooth structures or biomaterials [21]. Furthermore, hydrogen peroxide is produced by bacteria and leukocytes during inflammatory reactions and it has been linked to the corrosion of titanium surfaces [19]. Among the several oral microorganisms, S. mutans is one of the most relevant due to its capability to release lactic acid and to grow in acidic environments, becoming a prevailing corrosive microorganism. Souza et al. (2013) reported a decrease in the $\mathrm{pH}$ of the biofilm growth medium down to 4.0 over a period of $48 \mathrm{~h}$. A higher corrosion susceptibility was noted due to the lower titanium passive film capacitance in the presence of $S$. mutans biofilms when compared to the medium free of bacteria. Also, the data denoted a higher thickness of the $\mathrm{TiO}_{2}$-film in the absence of biofilms compared to the thin Ti oxide film formed 
on titanium covered with biofilms [18]. Additionally, C. Albicans (at $1 \times 10^{5} \mathrm{CFU} / \mathrm{mL}$ concentration) lowered the $\mathrm{pH}$ down to 3.0 due to the microbial metabolism with acidic products. The release of Ti ions from the titanium depends on the concentration of $C$. albicans in the medium that decrease the $\mathrm{pH}$ due to the microbial consumption of oxygen [17]. It should be emphasized that corroded surface of titanium implants is more susceptible to bacterial adhesion concerning the increase in roughness and modification of the surfaces; that may further acidify implant surroundings, accumulating corrosive products, and the corrosion processes continue [30].

The corrosion behavior of the titanium in different electrolytical solutions could be evaluated on the parameters of electrochemical techniques, such as open circuit potential (OCP), corrosion potential $\left(E_{c o r r}\right)$, corrosion current density, passivation current density, polarization resistance, electrochemical impedance, and equivalent circuit modeling (Table 1) [52]. In vitro electrochemical techniques offer the possibility to control parameters related to the material surface and medium, as seen in Table 1 [53]. On open corrosion conditions, the potential of the metal is determined in the ion conductive electrolyte solution although potentiodynamic or potentiostatic techniques are applied to impose the potential and measure the current density flowing on the surface in contact with the electrolyte solution [54]. However, determination of the corrosion current density from the polarization data is doubtful for passive metals. Standardized electrochemical test protocol was established by the American Society for Testing of Materials (West Conshohocken, USA) (ASTM G61-86 and G31-72) with three different electrode cells [55]. OCP evaluates the potential of an electron conductive material immersed in an ion conductive electrolyte and it is measured against a reference electrode [18]. Thus, OCP test denotes a trend to corrosion or not in the ion conductive electrolyte. For instance, Souza et al. (2012) findings showed the presence of a compact passive surface film on cp Ti after immersion in artificial saliva solution containing 0 up to $227 \mathrm{ppm} \mathrm{F}^{-}$over a period of $3 \mathrm{~h}$ in which the OCP increases to noble values. However, the OCP decreased on immersion in artificial saliva containing $12,300 \mathrm{ppm} \mathrm{F}^{-}$, although it stabilized after $6 \mathrm{~h}$ [35]. However, the electrochemical impedance spectroscopy (EIS) tests are useful for a proper evaluation of the state of the oxide thin film formed on the surfaces [35]. EIS assays are used to investigate the formation and growth of the oxide thin layer on the surface and its corrosion kinetics, as the capacitance and resistance determine the corrosion process [55,56]. For instance, the titanium oxide thin film capacitance represents the amount of electric charge stored on the titanium surface immersed in the ion conductive electrolyte solution. Moreover, the resistance of the passive film indicates the magnitude of resistance to the current flow on the surface [18]. Corrosion analyses are also combined with topographic evaluation of the morphological aspects of surfaces by scanning electron microscopy (SEM), optical microscopy, and atomic force microscopy (AFM). Additionally, roughness and weight loss analyses are further methods often used to evaluate the corrosion of surfaces. Chemical analyses can also be associated such as X-ray photoelectron spectroscopy (XPS) for atomic layers and Energy Dispersive X-ray (EDX) for chemical elemental analysis of the surfaces [6]. Additionally, the quantification of metal ions released can be analyzed by the plasma-mass spectrometry techniques [51].

Table 1. Summary of experimental works that evaluate titanium corrosion on simulated environment.

\begin{tabular}{|c|c|c|c|}
\hline Author (Year) & Materials & Methods & Outcomes \\
\hline $\begin{array}{l}\text { Sridhar et al. } \\
(2016)[21]\end{array}$ & $\begin{array}{l}\text { Large grit, acid-etched } c p \\
\text { Ti implants }\end{array}$ & $\begin{array}{l}\text { Mechanical Fatigue Test Simulating } \\
\text { Mild Oral Environment } \\
\text { Biofilm formation assays } \\
\text { SEM and EDX. }\end{array}$ & $\begin{array}{l}\text { Surface features such as } \\
\text { discoloration, fracture, surface } \\
\text { delamination, and fatigue } \\
\text { cracks were noted, suggesting } \\
\text { surface damage. } \\
\text { Surface damage in the form of } \\
\text { micropits. }\end{array}$ \\
\hline $\begin{array}{l}\text { Royhman et al. } \\
\text { (2015) [63] }\end{array}$ & Ti-6Al-4V disk & $\begin{array}{l}1,5 \text { and } 20 \mathrm{mg} / \mathrm{mL} \text { Nicotine at } 3.0 \text { or } \\
6.5 \mathrm{pH} \text {. } \\
\text { OCP, EIS, cyclic polarization. } \\
\text { White-light interferometry } \\
\text { microscope, SEM. }\end{array}$ & $\begin{array}{l}\text { At certain concentrations, } \\
\text { nicotine appeared to inhibit } \\
\text { local corrosion. However, it } \\
\text { also decreased the passive film } \\
\text { growth. }\end{array}$ \\
\hline
\end{tabular}


Table 1. Cont.

\begin{tabular}{|c|c|c|c|}
\hline Author (Year) & Materials & Methods & Outcomes \\
\hline $\begin{array}{l}\text { Perez et al. } \\
\text { (2014) [55] }\end{array}$ & Ti-6Al-4V disk & $\begin{array}{l}3 \text { mouthwash solutions and artificial } \\
\text { saliva (baseline) } \\
0.12 \% \text { chlorhexidine digluconate, } \\
0.053 \% \text { cetylpyridinium chloride } \\
\text { and } 3 \% \text { hydrogen peroxide). }\end{array}$ & $\begin{array}{l}\text { High aggressiveness of } \\
\text { hydrogen peroxide on the } \\
\text { Ti6Al4V alloy }\end{array}$ \\
\hline $\begin{array}{l}\text { Bhola et al. } \\
\text { (2013) [61] }\end{array}$ & $\begin{array}{l}\text { Ti6Al4V } \\
\text { Ti15Mo }\end{array}$ & $\begin{array}{l}\text { Listerine solution } \\
3 \text { time points: Initial (baseline), } 7 \\
\text { days and } 14 \text { days. } \\
\text { EIS, SEM, Potentiodynamic } \\
\text { Polarization. }\end{array}$ & $\begin{array}{l}\text { Listerine showing an increase } \\
\text { in corrosion rate on Ti6Al4V } \\
\text { alloy, and a decrease in } \\
\text { corrosion rate on Ti15Mo. }\end{array}$ \\
\hline $\begin{array}{l}\text { Souza et al. } \\
\text { (2013) [18] }\end{array}$ & $\mathrm{CP}$ titanium grade II & $\begin{array}{l}\text { Corrosion behavior of titanium in } \\
\text { contact with } S \text {. mutans in } \\
\text { Fusayama's artificial saliva. } \\
\text { OCP and EIS }\end{array}$ & $\begin{array}{l}\text { The presence of } S . \text { mutans } \\
\text { negatively affected the } \\
\text { corrosion resistance of the } \\
\text { titanium. }\end{array}$ \\
\hline $\begin{array}{l}\text { Souza et al. } \\
\text { (2012) [35] }\end{array}$ & $\mathrm{CP}$ titanium grade II & $\begin{array}{l}\text { Different Fluoride concentration: } \\
20,30 \text {, and } 227 \mathrm{ppm} \mathrm{F}^{-} \text {in a solution } \\
\text { of } \mathrm{pH} 5.5 \\
12,300 \mathrm{ppm} \mathrm{F}^{-} \text {in a solution of } \mathrm{pH} \\
6.5 \text {. } \\
\text { OCP, EIS, SEM, reciprocating-sliding } \\
\text { tests, and weight loss }\end{array}$ & $\begin{array}{l}\text { Synergistic effect of } \\
\text { reciprocating sliding wear and } \\
\text { fluoridated solutions at high } \\
\text { content of fluorides }\end{array}$ \\
\hline $\begin{array}{l}\text { Souza et al. } \\
\text { (2012) [33] }\end{array}$ & $\begin{array}{l}\text { CP titanium grade II } \\
\text { Ti6Al4V }\end{array}$ & $\begin{array}{l}\text { Different Fluoride concentration: } \\
20,30 \text {, and } 227 \mathrm{ppm} \mathrm{F}^{-} \text {in a solution } \\
\text { of } \mathrm{pH} 5.5 \\
12,300 \mathrm{ppm} \mathrm{F}^{-} \text {in a solution of } \mathrm{pH} \\
6.5 . \\
\text { OCP, potentiodynamic polarization, } \\
\text { EIS, SEM, AFM, ICP-MS }\end{array}$ & $\begin{array}{l}\text { Progressive degradation of } \\
\text { titanium was noted at a F} \\
\text { concentration of } 12,300 \mathrm{ppm} \text {. }\end{array}$ \\
\hline $\begin{array}{l}\text { Quaranta et al. } \\
\text { (2010) [62] }\end{array}$ & Cp Ti grade IV disk & $\begin{array}{l}\text { Fusayama artificial saliva (Fas), } \\
\text { ammine fluoride-stannous fluoride } \\
\text { (Am-SnF), } 0.2 \% \text { Chlorexidine (CHX) } \\
0.20 \% \text {, Fas with } 20 \% \text { Am-SnF and } \\
\text { Fas with } 20 \% \text { CHX. } \\
\text { OCP Ecorr, SEM and EDX }\end{array}$ & $\begin{array}{l}\text { SEM analysis showed a } \\
\text { marked localized corrosion on } \\
\text { titanium after } \\
\text { potentiodynamic polarization. }\end{array}$ \\
\hline $\begin{array}{l}\text { Rosifini et al. } \\
\text { (2007) [60] }\end{array}$ & $\begin{array}{l}\text { Cp Ti grade IV } \\
\text { Ti-10Mo }\end{array}$ & $\begin{array}{l}3 \text { mouthwashes: } \\
0.05 \% \text { sodium fluoride }+0.03 \% \\
\text { triclosan } \\
\text { (II) } 0.5 \mathrm{~g} / \mathrm{L} \text { cetylpyridinium chloride } \\
+0.05 \% \text { sodium fluoride; } \\
\text { (III) } 0.12 \% \text { chlorohexidine } \\
\text { digluconate. } \\
\text { OCP, potentiodynamic and } \\
\text { chronoamper- ometric curves }\end{array}$ & $\begin{array}{l}\text { Triclosan appeared to be more } \\
\text { aggressive than } \\
\text { cetylpyridinium chloride in } \\
\text { fluoride medium }\end{array}$ \\
\hline
\end{tabular}

Therapeutic mouthwashes are often indicated over the post-operative period after implant placement or during biofilm debridement process due to their antimicrobial properties. Strietzel et al. (1998) did not recommend the use of fluorinated solutions when the titanium implant surface is exposed to the oral environment, concerning the corrosion processes [59]. Another study noted the protective characteristics of the passive film formed on Ti15Mo alloy, and cp Ti was lower in $0.05 \%$ sodium fluoride $/ 0.03 \%$ triclosan mouthwashes than in solutions with $0.5 \mathrm{~g} / \mathrm{L}$ cetylpyridinium chloride $/ 0.05 \%$ sodium fluoride or $0.12 \%$ chlorohexidine digluconate [60]. Surfaces became increasingly rough with increased additions of mouthwashes, which interfered with the titanium oxide repassivation on Ti6Al4V alloys oxide [61]. On the other hand, the thickness of the titanium oxide film increases in contact with some acidic solutions, which are not capable of entirely damaging the passive film. That provides an enhanced corrosion resistance. Perez et al. (2014) evaluated the corrosion kinetics on the surface of Ti6Al4V alloy exposed to mouthwash solutions: $0.12 \%$ chlorhexidine digluconate, $0.053 \%$ cetylpyridinium chloride, $3 \%$ hydrogen peroxide, and artificial saliva. They conclude that hydrogen peroxide promoted significant surface changes, and the roughness measurement showed higher Ra values. In general, a higher corrosion trend is showed mainly at the initial process than after 
7 or 14 days. At initial evaluation, the group immersed in $0.12 \%$ chlorhexidine digluconate showed higher corrosion resistance values, even than in the group immersed in artificial saliva solution. On the other hand, the group immersed in hydrogen peroxide demonstrated a higher capability in exchanging ions with the electrolytic environment [55]. Another study revealed localized corrosion such as pitting and crevice corrosion on cpTi disks immersed in Chlorhexidine $0.2 \%$ [62]. However, further studies are required with daily cycles, two or three times a day, to mimic the scenario closest to the application of mouthwashes in the oral environment. Also, nicotine, the major constituent in cigarette smoke, was studied in regard to the corrosion behavior of titanium. Findings revealed that the corrosion rate of titanium decreased with a increase in nicotine concentration. However, the presence of nicotine also negatively affected the passive film formation, being that the passive current density and polarization resistance were reduced, leading to the worst overall surface performance [63].

\section{Biological Adverse Effects}

Titanium is not a bio-inert material since an active metallic material triggers chemical and biological reactions in the human body. On implant placement, immune response occurs on the titanium implant surface that depends on the chemical composition of the titanium oxide thin film and its debris, as illustrated in Figure 2 [64]. A marginal bone resorption around the titanium implant takes place and it can increase due to various factors inherent to the implant, prosthetics, patient, or surgical conditions. A pathological process with a clinical unfavorable dis-balanced foreign body reaction can be noted at soft-tissues with bleeding, namely mucositis, and leading to a progressive crestal bone loss and infection with suppuration, known as peri-implantitis [64,65]. Previous studies have shown that many factors trigger peri-implant disturbance and cause late failures of the dental implants involving peri-implant attachment injuries, bacteria-related inflammatory reactions, overloading or stress shielding, and debris from corrosion $[6,7,49,50,66,67]$. Each single factor inducing the chain inflammatory reactions is not entirely clear, but certainly, the synergistic effect among the factors worsens peri-implant inflammatory conditions.

An in vivo study revealed the release of ions/particles from the titanium implant surface into the human body, independently of the inflammatory response with or without peri-implantitis [68]. However, the concentration of titanium debris was higher in the group with peri-implantitis [68]. It is well known that the release of metallic ions and oxide particles induce chronic peri-implant inflammations since they act as foreign debris, and consequently, stimulate the attraction of macrophages, neutrophils, and T lymphocytes from immune system. Macrophages can generate active oxygen by releasing $\mathrm{H}_{2} \mathrm{O}_{2}$, which oxidizes the titanium surface and induces the release of titanium ions [9]. Submicron- and nano-scale titanium debris are phagocytized by the activated macrophages that also trigger the secretion of pro-inflammatory cytokine cascade, chemokines, growth factors, prostanoids, degradative enzymes, reactive oxygen species (ROS), and other factors [9]. In addition, multinucleated giant cells and osteoclasts are generated by the fusion of the macrophages surrounding the peri-implant region. At last, the chronic inflammation of peri-implant tissues leads to a progressive osteolytic process with the loss of bone anchorage to implant-supported prostheses $[4,12,16,18,50,67,69]$.

Titanium ions and particles induce cytotoxic effects depending on the size and concentration surrounding the cells $[4,11,12,70-72]$. Previous studies suggested that stimulation of the proinflammatory response is caused by submicron- and micro-scale particles [10,73]. Thus, the contact area of micro-scale particles is higher than on titanium macro-scale particles, which increase the dissolution of the titanium oxide thin film [73] while submicron-scale particles can be engulfed by the cells. Over $11 \mathrm{ppm}$, Ti ions showed to be cytotoxic, since they stimulate monocyte migration and may modulate the sensitivity of gingival epithelial cells to oral bacteria via toll-like receptors [74]. Other studies reported that a solution with 5 ppm Ti ions and Porphyromonas gingivalis-Lipopolysacaride-induced monocytes infiltration in the gingival and bone tissues via CCL2 cytokines $[74,75]$. Nevertheless, titanium ions might decrease bacterial growth due to their toxicity also on bacterial cells. In fact, a high concentration of Ti ions at $500 \mathrm{ppm}$ can also decrease the microbial cell viability [18]. 

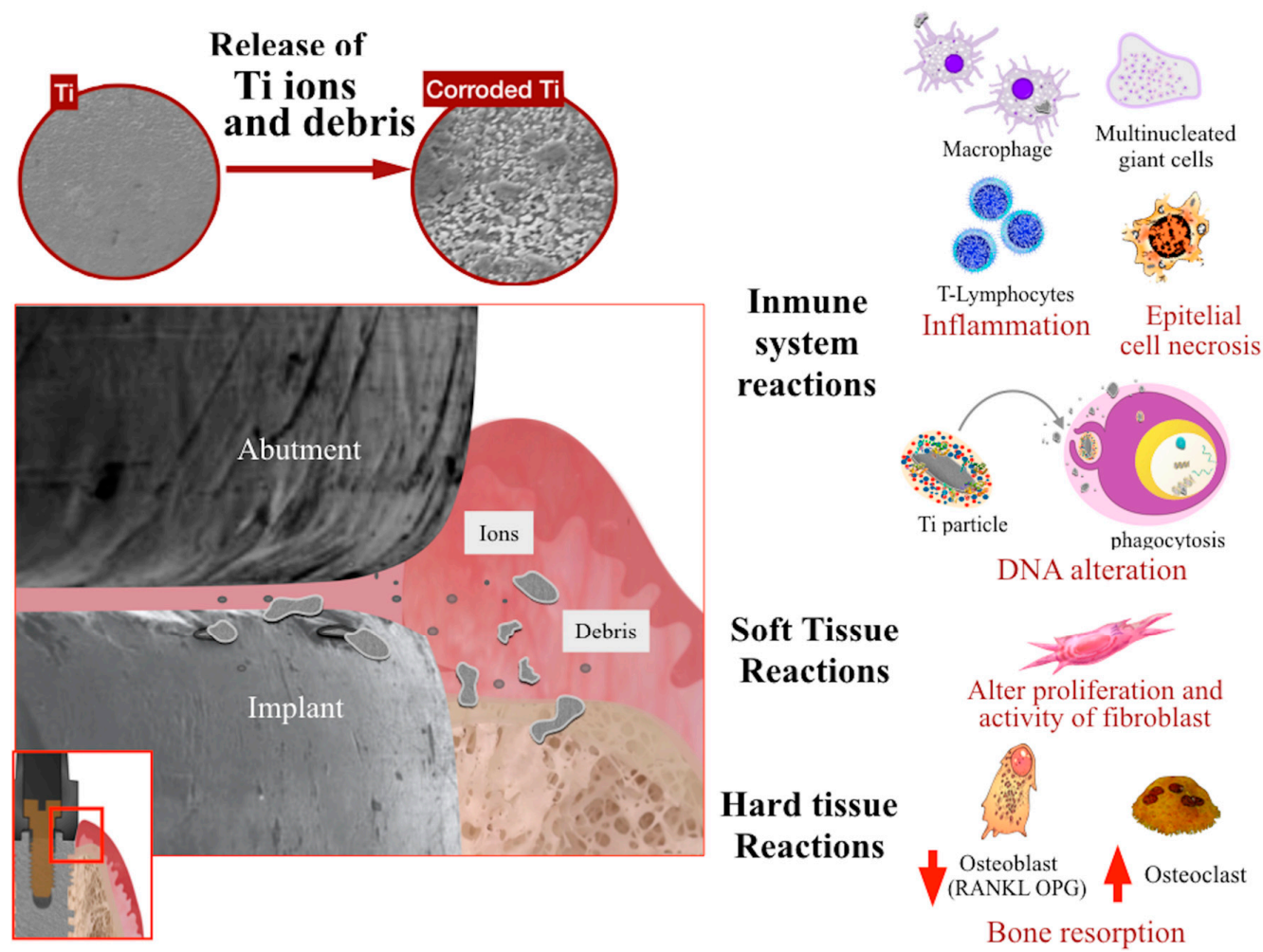

Figure 2. Release of Ti ions and the biological reactions. Adapted from Apaza-bedoya et al. 2017 [5].

The clinical evidence is limited and, therefore, the existent literature refers to the in vitro evaluation of retrieved failed implants. One study showed two implants failed cases, where in one case, signs of corrosion products on the soft tissue surrounding a failed implant were revealed [6]. The second case showed dark spots on the retrieved implants by SEM analyses [6]. Another case report study showed a retrieved failed dental implant after 15 years and the major cause of failure was related to the propagation of cracks [76]. The fracture surfaces were covered by mineral-based globules involving calcium, phosphorus, and oxygen [76]. Such a study suggested that firstly, oxygen or hydroxyl groups were adsorbed onto the Ti surface at regions with micro-cracks followed by phosphorous ions. At last, calcium cations were attracted to the regions and were arranged in a porous network [76]. Another study evaluated the surface of five titanium dental implants and abutments, which were retrieved due to peri-implantitis [21]. Scratches, pitting, cracks, discoloration, and surface delamination were noted on the surfaces of implants and abutments. Those findings indicated the aggressive effect of the acidic environment, which, possibly, triggered metal oxidation in the oral environment [21]. Most recently, an in vivo study evaluated 20 patients diagnosed with peri-implant mucositis [77]. In the group identified with "severe" mucositis, metal-like opaque particulate aggregates were identified as titanium particles in the peri-implant tissues of 12 patients [77].

\section{Concluding Remarks}

Although titanium and its alloys have demonstrated desired properties that guarantee the high clinical success rate of dental implant treatment over these years, mechanical/biological complications are often found in clinical practice. Such failures are also related to corrosion pathways. Indeed, the biomaterial faces a complex oral environment, which under the effect of intrinsic and extrinsic factors, may negatively affect the nature, chemical composition, and thickness of the protective titanium oxide thin layer. As a consequence, the corrosion behavior of titanium dental implants is dependent on the intrinsic and extrinsic factors. The literature confirms that biofilm accumulation induces corrosion on the titanium surfaces due to the presence of acidic substances from microbial metabolism. Additionally, saliva can suffer $\mathrm{pH}$ changes when inflammatory or infection processes 
take place at the peri-implant tissues. Acidic substances from diet contribute to microbial metabolism and $\mathrm{pH}$ decrease in saliva. Furthermore, corrosive substances like fluorides and acidic substances from prophylactic products or bleaching treatment can alter the corrosion behavior of titanium dental implants. The release of Ti ions and particles results in a material loss that can promote significant changes on titanium dental implant surface. Micro-, submicron, and nano-scale Ti debris cause cytotoxic effects in the peri-implant tissues and on the size, shape, and concentration surrounding the cells. However, clinical evidence is limited. Failed dental implant cases shown signs of corrosion on titanium surfaces and the presence of debris in the peri-implant tissues. Besides clinical findings, the experimental analyses of the peri-implant tissues are questionable. The summary of the results founded suggest further investigations, as well as updated protocols in the clinical practice. Future clinical studies with an appropriate number of participants are required for conclusive results on the relationship of different implant debris on the peri-implant tissues.

Funding: This study was supported by FCT-Portugal (UID/EEA/04436/2013, NORTE-01-0145-FEDER- 000018 - HAMaBICo, POCI-01-0145-FEDER-031035_LaserMULTICER) and CNPq-Brazil (CNPq/UNIVERSAL/421229/ 2018-7).

Conflicts of Interest: The authors declare no conflict of interest.

\section{References}

1. Duraccio, D.; Mussano, F.; Faga, M.G. Biomaterials for dental implants: Current and future trends. J. Mater. Sci. 2015, 50, 4779-4812. [CrossRef]

2. Steinemann, S.G. Titanium-The material of choice? Periodontol. 2000 1998, 17, 7-21. [CrossRef] [PubMed]

3. Souza, J.C.M.; Henriques, M.; Teughels, W.; Ponthiaux, P.; Celis, J.-P.; Rocha, L.A. Wear and Corrosion Interactions on Titanium in Oral Environment: Literature Review. J. Bio- Tribo-Corrosion 2015, 1, 13. [CrossRef]

4. Noronha Oliveira, M.; Schunemann, W.V.H.; Mathew, M.T.; Henriques, B.; Magini, R.S.; Teughels, W.; Souza, J.C.M. Can degradation products released from dental implants affect peri-implant tissues? J. Periodontal Res. 2018, 53,1-11. [CrossRef] [PubMed]

5. Apaza-Bedoya, K.; Tarce, M.; Benfatti, C.; Henriques, B.; Mathew, M.T.; Teughels, W.; Souza, J.C.M. Synergistic interactions between corrosion and wear at titanium-based dental implant connections: A scoping review. J. Periodontal Res. 2017, 52, 946-954. [CrossRef]

6. Mouhyi, J.; Dohan Ehrenfest, D.M.; Albrektsson, T. The Peri-Implantitis: Implant Surfaces, Microstructure, and Physicochemical Aspects. Clin. Implant Dent. Relat. Res. 2012, 14, 170-183. [CrossRef]

7. Rodrigues, D.C.; Valderrama, P.; Wilson, T.G.; Palmer, K.; Thomas, A.; Sridhar, S.; Adapalli, A.; Burbano, M.; Wadhwani, C. Titanium corrosion mechanisms in the oral environment: A retrieval study. Materials 2013, 6, 5258-5274. [CrossRef]

8. Wilson, T.G.; Valderrama, P.; Burbano, M.; Blansett, J.; Levine, R.; Kessler, H.; Rodrigues, D.C. Foreign Bodies Associated With Peri-Implantitis Human Biopsies. J. Periodontol. 2015, 9-15. [CrossRef]

9. Hanawa, T. Metal ion release from metal implants. Mater. Sci. Eng. C 2004, 24, 745-752. [CrossRef]

10. Pettersson, M.; Kelk, P.; Belibasakis, G.N.; Bylund, D.; Molin Thorén, M.; Johansson, A. Titanium ions form particles that activate and execute interleukin-1 $\beta$ release from lipopolysaccharide-primed macrophages. J. Periodontal Res. 2017, 52, 21-32. [CrossRef]

11. Alrabeah, G.O.; Brett, P.; Knowles, J.C.; Petridis, H. The effect of metal ions released from different dental implant-abutment couples on osteoblast function and secretion of bone resorbing mediators. J. Dent. 2017, 66, 91-101. [CrossRef] [PubMed]

12. Apaza-Bedoya, K.; Bijukumar, D.; Benfatti, C.A.M.; Mathew, M.T.; da Silva, J.S.P.; Souza, J. Adverse local and systemic effect of nanoparticles released from oral and cranio-maxillofacial implants. In Nanostructured Biomaterials for Cranio-Maxillofacial and Oral Applications; Elsevier: Amsterdam, The Netherlands, 2018; pp. 63-79, ISBN 9780128146217.

13. Humphrey, S.P.; Williamson, R.T. A review of saliva: Normal composition, flow, and function. J. Prosthet. Dent. 2001, 85, 162-169. [CrossRef] [PubMed]

14. Dodds, M.W.J.; Johnson, D.A.; Yeh, C.-K. Health benefits of saliva: A review. J. Dent. 2005, 33, $223-233$. [CrossRef] [PubMed] 
15. Asri, R.I.M.; Harun, W.S.W.; Samykano, M.; Lah, N.A.C.; Ghani, S.A.C.; Tarlochan, F.; Raza, M.R. Corrosion and surface modification on biocompatible metals: A review. Mater. Sci. Eng. C 2017, 77, 1261-1274. [CrossRef]

16. Mathew, M.T.; Abbey, S.; Hallab, N.J.; Hall, D.J.; Sukotjo, C.; Wimmer, M.A. Influence of pH on the tribocorrosion behavior of $\mathrm{CpTi}$ in the oral environment: Synergistic interactions of wear and corrosion. J. Biomed. Mater. Res. Part B Appl. Biomater. 2012, 100, 1662-1671. [CrossRef]

17. Suito, H.; Iwawaki, Y.; Goto, T.; Tomotake, Y.; Ichikawa, T. Oral Factors Affecting Titanium Elution and Corrosion: An In Vitro Study Using Simulated Body Fluid. PLoS ONE 2013, 8, e66052. [CrossRef]

18. Souza, J.C.M.; Ponthiaux, P.; Henriques, M.; Oliveira, R.; Teughels, W.; Celis, J.P.; Rocha, L.A. Corrosion behaviour of titanium in the presence of Streptococcus mutans. J. Dent. 2013, 41, 528-534. [CrossRef]

19. Mabilleau, G.; Bourdon, S.; Joly-Guillou, M.L.; Filmon, R.; Baslé, M.F.; Chappard, D. Influence of fluoride, hydrogen peroxide and lactic acid on the corrosion resistance of commercially pure titanium. Acta Biomater. 2006, 2, 121-129. [CrossRef]

20. Souza, J.C.M.; Henriques, M.; Oliveira, R.; Teughels, W.; Celis, J.-P.; Rocha, L.A. Do oral biofilms influence the wear and corrosion behavior of titanium? Biofouling 2010, 26, 471-478. [CrossRef]

21. Sridhar, S.; Abidi, Z.; Wilson, T.G.; Valderrama, P.; Wadhwani, C.; Palmer, K.; Rodrigues, D.C. In vitro evaluation of the effects of multiple oral factors on dental implants surfaces. J. Oral Implantol. 2016, 42, 248-257. [CrossRef]

22. Harada, R.; Kokubu, E.; Kinoshita, H.; Yoshinari, M.; Ishihara, K.; Kawada, E.; Takemoto, S. Corrosion behavior of titanium in response to sulfides produced by Porphyromonas gingivalis. Dent. Mater. 2018, 34, 183-191. [CrossRef] [PubMed]

23. Cruz, H.V.; Souza, J.C.M.; Henriques, M.; Rocha, L.A.; Cruz, H.V.; Souza, J.C.M.; Henriques, M.; Rocha, L.A. Tribocorrosion and Bio-Tribocorrosion in the Oral Environment: The Case of Dental Implants; Nova Science Publishers, Inc.: Hauppauge, NY, USA, 2011; ISBN 978-1-61470-056-2.

24. Juanito, G.M.; Morsch, C.S.; Benfatti, C.A.; Fredel, M.C.; Magini, R.S.; Souza, J.C. Effect of Fluoride and Bleaching Agents on the Degradation of Titanium: Literature Review. Dentistry 2015, 5, 1-6. [CrossRef]

25. Nakagawa, M.; Matsuya, S.; Shiraishi, T.; Ohta, M. Effect of Fluoride Concentration and pH on Corrosion Behavior of Titanium for Dental Use. J. Dent. Res. 1999, 78, 1568-1572. [CrossRef] [PubMed]

26. Manam, N.S.; Harun, W.S.W.; Shri, D.N.A.; Ghani, S.A.C.; Kurniawan, T.; Ismail, M.H.; Ibrahim, M.H.I. Study of corrosion in biocompatible metals for implants: A review. J. Alloys Compd. 2017, 701, 698-715. [CrossRef]

27. Olmedo, D.G.; Tasat, D.R.; Duffó, G.; Guglielmotti, M.B.; Cabrini, R.L. The issue of corrosion in dental implants: A review. Acta Odontol. Latinoam. 2009, 22, 3-9.

28. Chaturvedi, T.P. An overview of the corrosion aspect of dental implants (titanium and its alloys). Indian J. Dent. Res. 2009, 20, 91. [CrossRef]

29. Williams, D.F. Corrosion of implant materials. Annu. Rev. Mater. Sci. 1976, 6, 237-266. [CrossRef]

30. Manivasagam, G.; Dhinasekaran, D.; Rajamanickam, A. Biomedical Implants: Corrosion and its Prevention-A Review. Recent Pat. Corros. Sci. 2010, 2, 40-54. [CrossRef]

31. Agarwal, A.; Tyagi, A.; Ahuja, A.; Kumar, N.; De, N.; Bhutani, H. Corrosion aspect of dental implants-An overview and literature review. Open J. Stomatol. 2014, 4, 56-60. [CrossRef]

32. Adya, N.; Alam, M.; Ravindranath, T.; Mubeen, A.; Saluja, B. Corrosion in titanium dental implant-Literature review. J. Indian Prosthodont. Soc. 2005, 5, 126-131. [CrossRef]

33. Souza, J.C.M.; Barbosa, S.L.; Ariza, E.A.; Henriques, M.; Teughels, W.; Ponthiaux, P.; Celis, J.P.; Rocha, L.A. How do titanium and Ti6Al4V corrode in fluoridated medium as found in the oral cavity? An in vitro study. Mater. Sci. Eng. C 2015, 47, 384-393. [CrossRef] [PubMed]

34. Nikolopoulou, F. Saliva and dental implants. Implant Dent. 2006, 15, 372-376. [CrossRef] [PubMed]

35. Souza, J.C.M.; Barbosa, S.L.; Ariza, E.; Celis, J.P.; Rocha, L.A. Simultaneous degradation by corrosion and wear of titanium in artificial saliva containing fluorides. Wear 2012, 292-293, 82-88. [CrossRef]

36. Fürst, M.M.; Salvi, G.E.; Lang, N.P.; Persson, G.R. Bacterial colonization immediately after installation on oral titanium implants. Clin. Oral Implants Res. 2007, 18, 501-508. [CrossRef]

37. Teughels, W.; Assche, N.; Sliepen, I.; Quirynen, M. Effect of Material Characteristics and/or Surface Topography on Biofilm Development. Clin. Oral Implant. Res. 2006, 17 (Suppl. S2), 68-81. [CrossRef]

38. Quirynen, M.; Van Steenberghe, D. Bacterial colonization of the internal part of two-stage implants. An in vivo study. Clin. Oral Implant. Res. 1993, 4, 158-161. [CrossRef] 
39. Prado, A.M.; Pereira, J.; Henriques, B.; Benfatti, C.A.; Magini, R.S.; López-López, J.; Souza, J.C. Biofilm Affecting the Mechanical Integrity of Implant-Abutment Joints. Int. J. Prosthodont. 2016, 29, 381-383. [CrossRef]

40. Souza, J.C.M.; Galarraga-Vinueza, M.E.; Henriques, B.; Hotza, D.; Boccaccini, A.R. Current state of nanostructured biomaterials for oral and cranio-maxillofacial rehabilitation. In Nanostructured Biomaterials for Cranio-Maxillofacial and Oral Applications; Elsevier: Amsterdam, The Netherlands, 2018; pp. 1-12, ISBN 9780128146217.

41. Oshida, Y.; Tuna, E.B.; Aktören, O.; Gençay, K. Dental implant systems. Int. J. Mol. Sci. 2010, 11, 1580-1678. [CrossRef]

42. Hanawa, T. A comprehensive review of techniques for biofunctionalization of titanium. J. Periodontal Implant Sci. 2011, 41, 263-272. [CrossRef]

43. Souza, J.C.M.; Bins-Ely, L.; Sordi, M.B.; Magini, R.S.; Aparicio, C.; Shokuhfar, T.; Cooper, L. Nanostructured surfaces of cranio-maxillofacial and dental implants. In Nanostructured Biomaterials for Cranio-Maxillofacial and Oral Applications; Elsevier: Amsterdam, The Netherlands, 2018; pp. 13-40.

44. Hryniewicz, T.; Rokicki, R.; Rokosz, K. Corrosion and surface characterization of titanium biomaterial after magnetoelectropolishing. Surf. Coat. Technol. 2009, 203, 1508-1515. [CrossRef]

45. Smeets, R.; Stadlinger, B.; Schwarz, F.; Beck-broichsitter, B.; Jung, O.; Precht, C.; Kloss, F.; Gröbe, A.; Heiland, M.; Ebker, T. Impact of Dental Implant Surface Modifications on Osseointegration. Biomed Res. Int. 2016. [CrossRef] [PubMed]

46. Gaviria, L.; Salcido, J.P.; Guda, T.; Ong, J.L. Current trends in dental implants. J. Korean Assoc. Oral Maxillofac. Surg. 2014, 40, 50. [CrossRef] [PubMed]

47. Huang, Y.; Han, S.; Pang, X.; Ding, Q.; Yan, Y. Electrodeposition of porous hydroxyapatite/calcium silicate composite coating on titanium for biomedical applications. Appl. Surf. Sci. 2013, 271, 299-302. [CrossRef]

48. Janković, A.; Eraković, S.; Vukašinović-Sekulić, M.; Mišković-Stanković, V.; Park, S.J.; Rhee, K.Y. Graphene-based antibacterial composite coatings electrodeposited on titanium for biomedical applications. Prog. Org. Coat. 2015, 83, 1-10. [CrossRef]

49. Bhola, R.; Bhola, S.M.; Mishra, B.; Olson, D.L. Corrosion in Titanium Dental Implants/Prostheses-A Review. Trends Biomater. Artif. Organs Int. J. 2011, 25, 34-46. [CrossRef]

50. Patterson, S.P.; Daffner, R.H.; Gallo, R.A. Electrochemical Corrosion of Metal Implants. Am. J. Roentgenol. 2005, 1219-1222. [CrossRef]

51. Alrabeah, G.O.; Knowles, J.C.; Petridis, H. Reduction of Tribocorrosion Products When Using the Platform-Switching Concept. J. Dent. Res. 2018, 97, 995-1002. [CrossRef]

52. Grotberg, J.; Hamlekhan, A.; Butt, A.; Patel, S.; Royhman, D.; Shokuhfar, T.; Sukotjo, C.; Takoudis, C.; Mathew, M.T. Thermally oxidized titania nanotubes enhance the corrosion resistance of Ti6Al4V. Mater. Sci. Eng. C 2016, 59, 677-689. [CrossRef]

53. Mischler, S. Triboelectrochemical techniques and interpretation methods in tribocorrosion: A comparative evaluation. Tribol. Int. 2008, 41, 573-583. [CrossRef]

54. Landolt, D.; Mischler, S.; Stemp, M.; Barril, S. Third body effects and material fluxes in tribocorrosion systems involving a sliding contact. Wear 2004, 256, 517-524. [CrossRef]

55. Faverani, L.P.; Barao, V.A.R.; Pires, M.F.A.; Yuan, J.C.C.; Sukotjo, C.; Mathew, M.T.; Assunção, W.G. Corrosion kinetics and topography analysis of Ti-6Al-4V alloy subjected to different mouthwash solutions. Mater. Sci. Eng. C 2014, 43, 1-10. [CrossRef]

56. Faverani, L.P.; Fogaça, J.F.; Machado, T.; Silva, E.A.; Barão, V.A.R.; Assunção, W.G. Does Surface Topography Improve Electrochemical Behavior of Ti-6Al-4V Alloy in Different Saliva pH Levels? J. Bio- Tribo-Corrosion 2015, 1, 20. [CrossRef]

57. Contu, F.; Elsener, B.; Böhni, H. A study of the potentials achieved during mechanical abrasion and the repassivation rate of titanium and Ti6Al4V in inorganic buffer solutions and bovine serum. Electrochim. Acta 2004, 50, 33-41. [CrossRef]

58. Lori, J.A.; Nok, A.J. Mechanism of adsorption of mucin to titanium in vitro. Biomed. Mater. Eng. 2004, 14, 557-563. [PubMed]

59. Strietzel, R.; Hösch, A.; Kalbfleisch, H.; Buch, D. In vitro corrosion of titanium. Biomaterials 1998, 19, 1495-1499. [CrossRef] 
60. Alves Rezende, M.C.R.; Alves, A.P.R.; Codaro, E.N.; Dutra, C.A.M. Effect of commercial mouthwashes on the corrosion resistance of Ti-10Mo experimental alloy. J. Mater. Sci. Mater. Med. 2007, 18, 149-154. [CrossRef] [PubMed]

61. Bhola, R.; Chandra, C.; Alabbas, F.M.; Kundu, S.; Mishra, B.; Olson, D.L. Corrosion response of Ti6Al4V and Ti15Mo dental implant alloys in the presence of listerine oral rinse. Int. J. Corros. 2013, 2013. [CrossRef]

62. Quaranta, A.; Ronconi, L.F.; Di Carlo, F.; Vozza, I.; Quaranta, M. Electrochemical behaviour of titanium in ammine and stannous fluoride and chlorexidine $0.2 \%$ mouthwashes. Int. J. Immunopathol. Pharmacol. 2010, 23, 335-343. [CrossRef]

63. Royhman, D.; Dominguez-Benetton, X.; Yuan, J.C.C.; Shokuhfar, T.; Takoudis, C.; Mathew, M.T.; Sukotjo, C. The Role of Nicotine in the Corrosive Behavior of a Ti-6Al-4V Dental Implant. Clin. Implant Dent. Relat. Res. 2015, 17, e352-e363. [CrossRef]

64. Albrektsson, T.; Dahlin, C.; Jemt, T.; Sennerby, L.; Turri, A.; Wennerberg, A. Is marginal bone loss around oral implants the result of a provoked foreign body reaction? Clin. Implant Dent. Relat. Res. 2014, 16, 155-165. [CrossRef]

65. Schwarz, F.; Derks, J.; Monje, A.; Wang, H.L. Peri-implantitis. J. Clin. Periodontol. 2018, 45, S246-S266. [CrossRef] [PubMed]

66. Safioti, L.M.; Kotsakis, G.A.; Pozhitkov, A.E.; Chung, W.O.; Daubert, D.M. Increased Levels of Dissolved Titanium Are Associated With Peri-Implantitis-A Cross-Sectional Study. J. Periodontol. 2017, 88, 436-442. [CrossRef] [PubMed]

67. Balamurugan, A.; Rajeswari, S.; Balossier, G.; Rebelo, A.H.S.; Ferreira, J.M.F. Corrosion aspects of metallic implants-An overview. Mater. Corros. 2008, 59, 855-869. [CrossRef]

68. Olmedo, D.G.; Nalli, G.; Verdú, S.; Paparella, M.L.; Cabrini, R.L. Exfoliative Cytology and Titanium Dental Implants: A Pilot Study. J. Periodontol. 2013, 84, 78-83. [CrossRef]

69. Broggini, N.; McManus, L.M.; Hermann, J.S.; Medina, R.; Schenk, R.K.; Buser, D.; Cochran, D.L. Peri-implant inflammation defined by the implant-abutment interface. J. Dent. Res. 2006, 85, 473-478. [CrossRef]

70. Tamura, K.; Takashi, N.; Kumazawa, R.; Watari, F.; Totsuka, Y. Effects of Particle Size on Cell Function and Morphology in Titanium and Nickel. Mater. Trans. 2002, 43, 3052-3057. [CrossRef]

71. Kumazawa, R.; Watari, F.; Takashi, N.; Tanimura, Y.; Uo, M.; Totsuka, Y. Effects of Ti ions and particles on neutrophil function and morphology. Biomaterials 2002, 23, 3757-3764. [CrossRef]

72. Okuda-shimazaki, J.; Takaku, S.; Kanehira, K.; Sonezaki, S.; Taniguchi, A. Effects of titanium dioxide nanoparticle aggregate size on gene expression. Int. J. Mol. Sci. 2010, 11, 2383-2392. [CrossRef]

73. Franchi, M.; Orsini, E.; Martini, D.; Ottani, V.; Fini, M. Destination of titanium particles detached from titanium plasma sprayed implants. Micron 2007, 38, 618-625. [CrossRef]

74. Makihira, S.; Mine, Y.; Nikawa, H.; Shuto, T.; Iwata, S.; Hosokawa, R.; Kamoi, K.; Okazaki, S.; Yamaguchi, Y. Titanium ion induces necrosis and sensitivity to lipopolysaccharide in gingival epithelial-like cells. Toxicol. In Vitro 2010, 24, 1905-1910. [CrossRef]

75. Wachi, T.; Shuto, T.; Shinohara, Y.; Matono, Y.; Makihira, S. Release of titanium ions from an implant surface and their effect on cytokine production related to alveolar bone resorption. Toxicology 2015, 327, 1-9. [CrossRef] [PubMed]

76. Manda, M.G.; Psyllaki, P.P.; Tsipas, D.N.; Koidis, P.T. Clinical Deviee-related article observations on an In-vivo failure of a titanium dental implant/abutment screw system: A case report. J. Biomed. Mater. Res. Part B Appl. Biomater. 2009, 89, 264-273. [CrossRef] [PubMed]

77. Penmetsa, S.D.; Shah, R.; Thomas, R.; Kumar, A.T.; Gayatri, P.D.; Mehta, D. Titanium particles in tissues from peri-implant mucositis: An exfoliative cytology-based pilot study. J. Indian Soc. Periodontol. 2017, 21, 192. [CrossRef] [PubMed]

(C) 2020 by the authors. Licensee MDPI, Basel, Switzerland. This article is an open access article distributed under the terms and conditions of the Creative Commons Attribution (CC BY) license (http://creativecommons.org/licenses/by/4.0/). 